\title{
Effect of Prednisolone on the Urinary Excretion of Nicotinamide and Its Metabolites in Rats Fed with a Niacin-free Diet
}

\author{
Katsumi SHibata \\ Department of Food Science and Nutrition, Teikoku Women's University, \\ Moriguchi, Osaka 570, Japan \\ Received November 2, 1989
}

\begin{abstract}
Adrenal cortical hormone seems to play an important role in de novo NAD biosynthesis from tryptophan. Therefore, the effects of prednisolone, a synthetic adrenal cortical hormone, on the urinary excretion of nicotinamide and such catabolic metabolites as $N^{1}$-methylnicotinamide (MNA), $N^{1}$ methyl-2-pyridone-5-carboxamide (2-Py) and $N^{1}$-methyl-4-pyridone-3-carboxamide (4-Py) were investigated. Rats fed with a niacin-free diet were intraperitoneally injected with prednisolone ( $3 \mathrm{mg} / \mathrm{rat}$ ) three times at 09:00, 13:00 and 17:00 hr on day 0 . As a result, the urinary excretion of nicotinamide, MNA, 2-Py and 4-Py was each higher in the prednisolone group than in the physiological saline group (for control) after 1 day; however, each excretion was lower in the prednisolone group than in control group after 3, 4, 5 and 6 days. On around the 7th day, the urinary excretion in the prednisolone group was restored to the control values. The initial rapid increase and subsequent decrease in the urinary excretion of nicotinamide and its metabolites by an injection of prednisolone is considered to be attributable to a respective elevation of the liver tryptophan oxygenase level and the liver aminocarboxymuconate-semialdehyde decarboxylase level.
\end{abstract}

The pituitary-adrenal system seems to play an important role in de novo NAD biosynthesis from tryptophan (Trp): [1] a glucocorticoid hormone load caused a rapid elevation of Trp oxygenase level ${ }^{1)}$; [2] only in hypophysectomized rats, aminocarboxymuconate-semialdehyde decarboxylase (ACMSDase) activity was elevated by an injection of adrenal cortical hormone ${ }^{2)}$; [3] ACMSDase activity decreased upon an adrenalectomy. ${ }^{3)}$

Sanada and Miyazaki ${ }^{4)}$ have reported that an injection of prednisolone, a synthetic adrenal cortical hormone which has potent glucocorticoid activity but no mineralocorticoid activity, ${ }^{5)}$ caused an increase in hypophysectomized rat liver ACMSDase activity, which plays an important role in de novo NAD biosynthesis from Trp. Higher ACMSDase activity generally means a lower formation of quinolinic acid and such metabolites as nicotinamide (Nam), $N^{1}$-methylnicotinamide (MNA), $N^{1}$-methyl-2-pyridone5-carboxamide (2-Py) and $N^{1}$-methyl-4-pyridone-3-carboxamide (4-Py). On the other hand, Blake and $\mathrm{Kun}^{6}$ have reported that an injection of hydrocortisone, an adrenal cortical hormone, caused an increase in liver Trp oxygenase activity, which is the initial enzyme in de novo NAD biosynthesis. Higher Trp oxygenase activity generally means a higher formation of quinolinic acid and its metabolites. This paper reports the effects of an injection of prednisolone on the urinary excretion of Nam, MNA, 2-Py and 4-Py from rats fed with a niacin-free diet.

\section{Materials and Methods}

Chemicals. MNA chloride was purchased from Tokyo Kasei Kogyo Co. (Tokyo, Japan). 2-Py and 4-Py were synthesized by the methods of Pullman and Colowick ${ }^{7}$ and Shibata et al., ${ }^{8)}$ respectively. Prednisolone was purchased from Wako Pure Chemical Industries (Osaka, Japan). All other chemicals used were of the highest purity available from commercial sources.

Animals and diet. Male rats of the Wistar strain (experiment I, 3-weeks old; experiment II, 8-weeks old) were purchased from Clea Japan Inc. (Tokyo, Japan). The rats were immediately placed in individual metabolic cages 
Table I. COMposition of THE DiET

\begin{tabular}{lc}
\hline & $\mathrm{g} / \mathrm{kg}$ of diet \\
\hline Vitamin-free casein $^{a}$ & 200 \\
L-Methionine $^{a}$ & 2 \\
$\alpha-$ Cornstarch $^{b}$ & 458 \\
Sucrose $^{a}$ & 230 \\
Corn oil $^{c}$ & 50 \\
Mineral mixture $^{d}$ (Oriental's ratio) & 50 \\
Vitamin mixture $^{e}$ & 10 \\
(Oriental's ratio, nicotinic acid-free) &
\end{tabular}

a Obtained from Wako Pure Chemical Industries (Osaka, Japan).

$b$ Obtained from Nichiden Kagaku Co. (Osaka, Japan).

c Obtained from Ajinomoto Co. (Tokyo, Japan).

d Obtained from Oriental Yeast Kogyo Co. (Tokyo, Japan). The composition is described in ref. 11.

e Obtained from Oriental Yeast Kogyo Co. (Tokyo, Japan). The composition is described in ref. 11.

(CT-10, obtained from Clea Japan) and fed with a nicotinic acid-free and $20 \%$ casein diet (Table I) ad libitum for 64 days (experiment I) and for 38 days (experiment II). This diet did not contain niacin; however, sufficient niacin can be synthesized from Trp in casein. In experiment I, rats $(n=5)$ were intraperitoneally injected with $3 \mathrm{mg}$ of prednisolone suspended in $1 \mathrm{ml}$ of sterilized saline/rat three times at 09:00, 13:00 and 17:00 hr on the 53rd day. In experiment II, rats $(n=5)$ were intraperitoneally injected with $3 \mathrm{mg}$ of prednisolone suspended in $1 \mathrm{ml}$ of sterilized saline/rat three times at 09:00, 13:00 and 17:00 hr on the 32 nd day. As a control, rats $(n=5)$ were intraperitoneally injected with $1 \mathrm{ml}$ of sterilized saline/rat three times at 09:00, 13:00 and 17:00 hr on the 32nd day. Urine samples were collected as indicated in Table II (experiment I) and Table III (experiment II).

The room temperature was kept at $22 \pm 2^{\circ} \mathrm{C}$ with a humidity of about $60 \%$, and a 12-hr light/dark cycle was maintained. Body weight and food intake were measured daily at around 09:00 after the injection of prednisolone.

Analyses. Urine values for Nam, 2-Py and 4-Py were simultaneously measured by the high-performance liquid chromatographic (HPLC) method of Shibata $e t$ al. ${ }^{8)}$ Urine values for MNA were measured by the HPLC method of Shibata. ${ }^{81}$

\section{Results}

\section{Experiment I}

Figure 1 shows the effect of prednisolone on the urinary excretion of Nam, MNA, 2-Py and 4-Py in rats fed with a niacin-free diet.

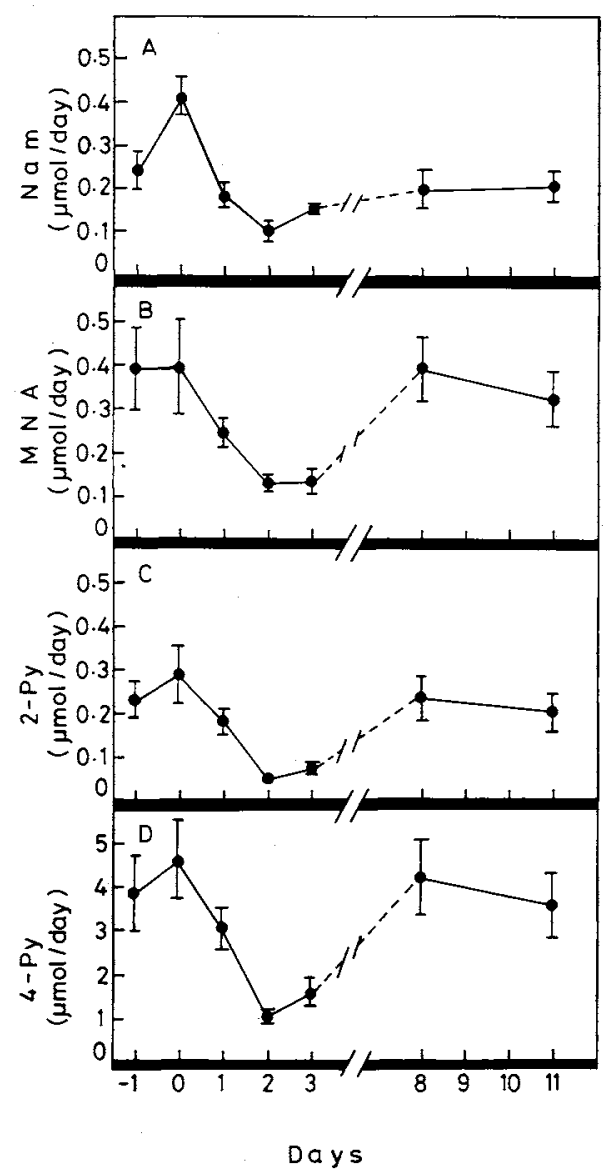

Fig. 1. Effect of Prednisolone on the Urinary Excretion of Nam (A), MNA (B), 2-Py (C) and 4-Py (D) (Experiment I).

For the experimental conditions, see Table II. Values are means $\pm S E M$ for five rats.

Prednisolone $(3 \mathrm{mg} / \mathrm{rat})$ was injected into the rats three times at 09:00, 13:00 and 17:00 hr. The day of injection was designated day 0 . Under these conditions, Nam, MNA, 2-Py and 4-Py were synthesized from only Trp. The urinary excretion of Nam, MNA, 2-Py and 4Py each tended to increase during the 1st day; however, each excretion decreased during the 3rd and 4th days as compared with the preinjection day (control values for day -1). These minimum values were observed on the 3rd day and 4th day, and each excretion had tended to revert to the control values thereafter. Each excretion had recovered to the preinjection value by the 9 th day. 
Table II. Effect of Prednisolone on the Tryptophan-Niacin Conversion Factor (EXPERIMENT I)

Male rats of the Wistar strain (3 weeks old) were fed with a nicotinic acid-free and $20 \%$ casein diet (see Table I) ad libitum for 64 days. The rats were then intraperitoneally injected with $3 \mathrm{mg}$ of prednisolone suspended in $1 \mathrm{ml}$ of sterilized saline/rat at $09: 00,13: 00$ and $17: 00 \mathrm{hr}$ on the 53rd day of the experiment. Urine samples were collected from $09: 00 \mathrm{hr}$ on the $52 \mathrm{nd}$ day to $09: 00 \mathrm{hr}$ on the 53rd day (day -1 ), from $09: 00$ hr on the 53 rd day to $09: 00 \mathrm{hr}$ on the 54 th day (day 1), from $09: 00 \mathrm{hr}$ on the 54 th day to $09: 00 \mathrm{hr}$ on the 55 th day (day 2), from $09: 00 \mathrm{hr}$ on the 55 th day to $09: 00 \mathrm{hr}$ on the $56 \mathrm{th}$ day (day 3), from $09: 00 \mathrm{hr}$ on the $56 \mathrm{th}$ day to $09: 00 \mathrm{hr}$ on the 57 th day (day 4), from $09: 00 \mathrm{hr}$ on the 6lst day to $09: 00 \mathrm{hr}$ on the $62 \mathrm{nd}$ day (day 9) and from $09: 00 \mathrm{hr}$ on the 64 th day to $09: 00 \mathrm{hr}$ on the 65 st day (day 12).

\begin{tabular}{|c|c|}
\hline & Prednisolone \\
\hline \multicolumn{2}{|l|}{ Day -1} \\
\hline Body weight gain (g/day) & $2.5 \pm 0.3$ \\
\hline Food intake (g/day) & $17.0 \pm 0.9$ \\
\hline $\begin{array}{l}\text { Trp intake }(\mu \mathrm{mol} / \mathrm{day})^{a} \\
(\mathrm{Nam}+\mathrm{MNA}+2-\mathrm{Py}+4-\mathrm{Py}) \text { excretion }\end{array}$ & $196 \pm 10$ \\
\hline$(\mu \mathrm{mol} /$ daily urine $)$ & $4.56 \pm 0.96$ \\
\hline Trp conversion factor ${ }^{b}$ & $51.8 \pm 11.1$ \\
\hline \multicolumn{2}{|l|}{ Day 1} \\
\hline Body weight gain (g/day) & $-11.6 \pm 0.5$ \\
\hline Food intake (g/day) & $13.6 \pm 0.7$ \\
\hline Trp intake $(\mu \mathrm{mol} / \mathrm{day})$ & $157 \pm 8$ \\
\hline $\begin{array}{l}\text { (Nam + MNA + } 2-\mathrm{Py}+4-\mathrm{Py}) \text { excretion } \\
(\mu \mathrm{mol} / \text { daily urine })\end{array}$ & $5.73+1.10$ \\
\hline Trp conversion factor & $32.0 \pm 6.2$ \\
\hline$-\cdots---$ & ---- \\
\hline \multicolumn{2}{|l|}{ Day 2} \\
\hline Body weight gain (g/day) & $-9.5 \pm 0.6$ \\
\hline Food intake (g/day) & $9.4 \pm 0.7$ \\
\hline Trp intake $(\mu \mathrm{mol} / \mathrm{day})$ & $108 \pm 8$ \\
\hline $\begin{array}{l}(\mathrm{Nam}+\mathrm{MNA}+2-\mathrm{Py}+4-\mathrm{Py}) \text { excretion } \\
(\mu \mathrm{mol} / \text { daily urine })\end{array}$ & $3.68 \pm 0.56$ \\
\hline Trp conversion factor & $31.5 \pm 4.1$ \\
\hline \multicolumn{2}{|l|}{ Day 3} \\
\hline Body weight gain (g/day) & $5.1 \pm 1.6$ \\
\hline Food intake $(\mathrm{g} /$ day $)$ & $12.5 \pm 0.9$ \\
\hline $\begin{array}{l}\text { Trp intake }(\mu \mathrm{mol} / \mathrm{day}) \\
(\mathrm{Nam}+\mathrm{MNA}+2-\mathrm{Py}+4-\mathrm{Py}) \text { excretion }\end{array}$ & $144 \pm 10$ \\
\hline ( $\mu \mathrm{mol} /$ daily urine) & $1.35 \pm 0.17$ \\
\hline Trp conversion factor & $110.3 \pm 11.1$ \\
\hline
\end{tabular}

\section{Day 4}

Body weight gain (g/day)

Food intake (g/day)

Trp intake ( $\mu \mathrm{mol} /$ day)

$(\mathrm{Nam}+\mathrm{MNA}+2-\mathrm{Py}+4-\mathrm{Py})$ excretion ( $\mu$ mol/daily urine)
Table II. (continued).

\begin{tabular}{|c|c|}
\hline & Prednisolone \\
\hline Trp conversion factor & $91.4 \pm 10.8$ \\
\hline$---\cdots--\cdots-\cdots-\cdots-\cdots$ & ------ \\
\hline \multicolumn{2}{|l|}{ Day 9} \\
\hline Body weight gain (g/day) & $2.2 \pm 0.4$ \\
\hline Food intake (g/day) & $17.8 \pm 1.3$ \\
\hline Trp intake $(\mu \mathrm{mol} /$ day $)$ & $205 \pm 15$ \\
\hline ( $\mu \mathrm{mol} /$ daily urine $)$ & $4.99 \pm 0.94$ \\
\hline Trp conversion factor & $46.4 \pm 7.5$ \\
\hline$--------\cdots-----$ & ----- \\
\hline \multicolumn{2}{|l|}{ Day 12} \\
\hline Body weight gain (g/day) & $1.9 \pm 0.4$ \\
\hline Food intake $(\mathrm{g} /$ day $)$ & $17.1 \pm 1.1$ \\
\hline Trp intake $(\mu \mathrm{mol} / \mathrm{day})$ & $197 \pm 12.7$ \\
\hline$(\mathrm{Nam}+\mathrm{MNA}+2-\mathrm{Py}+4-\mathrm{Py})$ excretion & \\
\hline ( $\mu \mathrm{mol} /$ daily urine $)$ & $4.29 \pm 0.85$ \\
\hline Trp conversion factor & $51.9 \pm 8.2$ \\
\hline
\end{tabular}

a $\quad$ Trp intake $(\mu \mathrm{mol} /$ day $)=[$ food intake $(\mathrm{g} /$ day $) \times 0.903$ $\times 0.013 \times 0.2 \times 10^{6} \mathrm{~J} / 204$. 0.903 , protein content in casein; 0.013 , Trp content in casein; 0.2 , casein content in the diet.

${ }^{b}$ Trp conversion factor $=[\operatorname{Trp}$ intake $(\mu \mathrm{mol} / \mathrm{day})] /$ $[(\mathrm{Nam}+\mathrm{MNA}+2-\mathrm{Py}+4-\mathrm{Py})$ excretion $(\mu \mathrm{mol} / \mathrm{day})]$. Values are means \pm SEM for five rats.

Table II shows the effects of prednisolone on the body weight gain, food intake, Trp intake, sum of Nam, MNA, 2-Py and 4-Py excretion, and Trp conversion factor [Trp intake $(\mu \mathrm{mol} / \mathrm{day}) /(\mathrm{Nam}+\mathrm{MNA}+2-\mathrm{Py}+4-\mathrm{Py}$ excretion) in $\mu \mathrm{mol} /$ daily urine]. Body weight decreased during the 1 st and 2 nd days after the prednisolone injection, and increased again thereafter. Food intake also decreased during the 1 st, 2 nd and 3 rd days after the injection as compared with the pre-injection day. The urinary excretion of the sum of Nam, MNA, 2-Py and 4-Py tended to be higher during the 1st day than in day -1 (control value). However, this value decreased after 2, 3 and 4 days as compared with the control. The minimum value of the sum of Nam, MNA, 2-Py and 4Py excretion was observed on the 3 rd day. By the 9th day, this value had recovered to the control level. The Trp conversion factor under normal conditions is around $50 \cdot$ (day -1 , and days 9 and 12). The lowest Trp conversion factor, namely the highest Nam and its me- 
tabolite formation from Trp, was observed at days 1 and 2 (around 30), and the highest Trp conversion factor, namely the lowest Nam and its metabolite formation from Trp, was observed at day 3 (around 110).

\section{Experiment II}

The experiment was repeated to determine the initial increase and subsequent decrease in the urinary excretion of Nam and its metabolites by an injection of prednisolone. This time, the age of the rats and the feeding period of the niacin-free diet were selected differently to check that the prednisolone effects were not

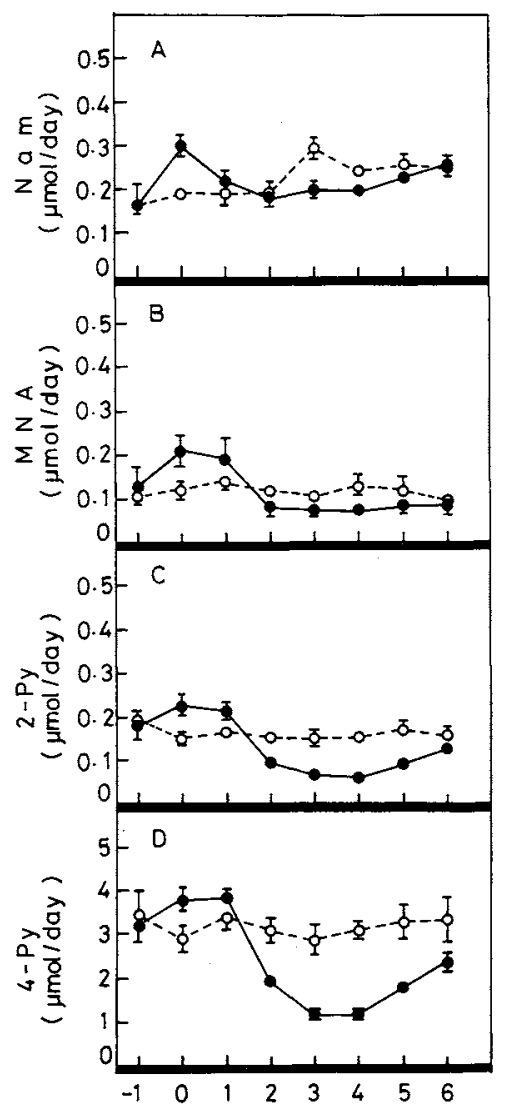

Day 5

Fig. 2. Effect of Prednisolone on the Urinary Excretion of Nam (A), MNA (B), 2-Py (C) and 4-Py (D) (Experiment II).

For the experimental conditions, see Table III. $O$, control group; 0 , prednisolone group. Values are means \pm SEM for five rats.
Table III. Effect of Prednisolone on the TRYPTOPHAN-NIACiN CONVERSION FACTOR (EXPERIMENT II)

Male rats of the Wistar strain ( 8 weeks old) were fed with a nicotinic acid-free and $20 \%$ casein diet (see Table I) ad libitum for 38 days. The rats were intraperitoneally injected with $3 \mathrm{mg}$ of prednisolone suspended in $1 \mathrm{ml}$ of sterilized saline/rat at $09: 00,13: 00$ and $17: 00 \mathrm{hr}$ on the 32 nd day of the experiment. As a control, the rats were injected with $1 \mathrm{ml}$ of sterilized saline at 09:00, 13:00 and $17: 00 \mathrm{hr}$ on the $32 \mathrm{nd}$ day. Urine samples were collected from $09: 00 \mathrm{hr}$ on the 31 st day to $09: 00 \mathrm{hr}$ on the $32 \mathrm{nd}$ day (day - 1), from $09: 00 \mathrm{hr}$ on the $32 \mathrm{nd}$ day to $09: 00 \mathrm{hr}$ on the 33 rd day (day 1), from $09: 00 \mathrm{hr}$ on the 33 rd day to $09: 00 \mathrm{hr}$ on the 34 th day (day 2), from $09: 00 \mathrm{hr}$ on the 34 th day to $09: 00 \mathrm{hr}$ on the 35 th day (day 3), from $09: 00 \mathrm{hr}$ on the $35 \mathrm{th}$ day to $09: 00 \mathrm{hr}$ on the 36 th day (day 4), from $09: 00 \mathrm{hr}$ on the $36 \mathrm{th}$ day to $09: 00 \mathrm{hr}$ on the 37 th day (day 5), from $09: 00 \mathrm{hr}$ on the 37 th day to $09: 00 \mathrm{hr}$ on the $38 \mathrm{th}$ day (day 6), and from $09: 00 \mathrm{hr}$ on the 38 th day to $09: 00 \mathrm{hr}$ on the 39 th day (day 7 ).

\begin{tabular}{|c|c|c|}
\hline & Control & Prednisolone \\
\hline \multicolumn{3}{|l|}{ Day -1} \\
\hline Body weight gain (g/day) & $1.5 \pm 0.2$ & $1.3 \pm 0.2$ \\
\hline Food intake (g/day) & $14.3 \pm 0.8$ & $15.4 \pm 0.3$ \\
\hline Trp intake $(\mu \mathrm{mol} / \mathrm{day})^{a}$ & $165 \pm 9$ & $177 \pm 3$ \\
\hline \multicolumn{3}{|c|}{$(\mathrm{Nam}+\mathrm{MNA}+2-\mathrm{Py}+4-\mathrm{Py})$ excretion } \\
\hline ( $\mu \mathrm{mol} / \mathrm{dail}$ y urine) & $3.86 \pm 0.62$ & $3.68 \pm 0.42$ \\
\hline Trp conversion factor ${ }^{b}$ & $50.0 \pm 9.9$ & $50.5 \pm 5.9$ \\
\hline---------- & ----- & ----- \\
\hline \multicolumn{3}{|l|}{ Day 1} \\
\hline Body weight gain (g/day) & $1.3 \pm 0.2$ & $-8.3 \pm 0.9$ \\
\hline Food intake (g/day) & $15.4 \pm 0.7$ & $16.8 \pm 0.8$ \\
\hline Trp intake $(\mu \mathrm{mol} / \mathrm{day})$ & $177 \pm 8$ & $193 \pm 9$ \\
\hline \multicolumn{3}{|c|}{$(\mathrm{Nam}+\mathrm{MNA}+2-\mathrm{Py}+4-\mathrm{Py})$ excretion } \\
\hline ( $\mu \mathrm{mol} /$ daily urine) & $3.41 \pm 0.36$ & $4.63 \pm 0.35$ \\
\hline Trp conversion factor & $55.7 \pm 5.7$ & $42.2 \pm 1.7$ \\
\hline--------- & 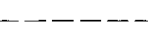 & 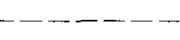 \\
\hline \multicolumn{3}{|l|}{ Day 2} \\
\hline Body weight gain (g/day) & $1.5 \pm 0.3$ & $-10.6 \pm 0.9$ \\
\hline Food intake (g/day) & $16.2 \pm 1.1$ & $9.1 \pm 1.1$ \\
\hline Trp intake ( $\mu \mathrm{mol} /$ day $)$ & $186 \pm 12$ & $105 \pm 13$ \\
\hline \multicolumn{3}{|c|}{$(\mathrm{Nam}+\mathrm{MNA}+2-\mathrm{Py}+4-\mathrm{Py})$ excretion } \\
\hline ( $\mu \mathrm{mol} /$ daily urine) & $3.95 \pm 0.32$ & $4.48 \pm 0.28$ \\
\hline Trp conversion factor & $50.0 \pm 2.7$ & $23.7 \pm 3.0$ \\
\hline---- & & \\
\hline \multicolumn{3}{|l|}{ Day 3} \\
\hline Body weight gain (g/day) & $2.1 \pm 0.3$ & $1.6 \pm 1.6$ \\
\hline Food intake (g/day) & $17.2 \pm 0.7$ & $11.3 \pm 1.3$ \\
\hline Trp intake $(\mu \mathrm{mol} / \mathrm{day})$ & $198 \pm 8$ & $130 \pm 15$ \\
\hline \multicolumn{3}{|c|}{$(\mathrm{Nam}+\mathrm{MNA}+2-\mathrm{Py}+4-\mathrm{Py})$ excretion } \\
\hline ( $\mu \mathrm{mol} /$ daily urine) & $3.70 \pm 0.32$ & $2.33 \pm 0.12$ \\
\hline Trp conversion factor & $55.6 \pm 3.3$ & $55.4 \pm 5.1$ \\
\hline
\end{tabular}

\section{Day 4}

Body weight gain (g/day)

Food intake (g/day)

$1.2 \pm 0.3$

$4.4 \pm 1.0$

$14.7 \pm 1.4 \quad 14.8 \pm 1.1$ 
Table III. (continued)

\begin{tabular}{|c|c|c|}
\hline & Control & Prednisolone \\
\hline Trp intake ( $\mu \mathrm{mol} /$ day $)$ & $169 \pm 16$ & $170 \pm 13$ \\
\hline \multicolumn{3}{|c|}{$(\mathrm{Nam}+\mathrm{MNA}+2-\mathrm{Py}+4-\mathrm{Py})$ excretion } \\
\hline ( $\mu \mathrm{mol} /$ daily urine) & $3.45 \pm 0.38$ & $1.58 \pm 0.10$ \\
\hline Trp conversion factor & $54.7 \pm 5.1$ & $108.6 \pm 10.4$ \\
\hline$---\cdots---\cdots$ & ----- & -----1 \\
\hline \multicolumn{3}{|l|}{ Day 5} \\
\hline Body weight gain (g/day) & $1.5 \pm 0.3$ & $2.3 \pm 0.8$ \\
\hline Food intake (g/day) & $14.0 \pm 2.1$ & $15.6 \pm 0.5$ \\
\hline Trp intake $(\mu \mathrm{mol} /$ day $)$ & $161 \pm 24$ & $179 \pm 6$ \\
\hline \multicolumn{3}{|c|}{$(\mathrm{Nam}+\mathrm{MNA}+2-\mathrm{Py}+4-\mathrm{Py})$ excretion } \\
\hline ( $\mu \mathrm{mol} /$ daily urine) & $3.66 \pm 0.21$ & $1.57 \pm 0.09$ \\
\hline Trp conversion factor & $47.4 \pm 4.2$ & $116.0 \pm 9.6$ \\
\hline$----\cdots-\cdots$ & $----\cdots$ & 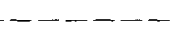 \\
\hline \multicolumn{3}{|l|}{ Day 6} \\
\hline Body weight gain (g/day) & $1.3 \pm 0.2$ & $1.9 \pm 0.3$ \\
\hline Food intake (g/day) & $15.5 \pm 1.9$ & $18.0 \pm 0.6$ \\
\hline Trp intake $(\mu \mathrm{mol} /$ day $)$ & $178 \pm 22$ & $207 \pm 7$ \\
\hline \multicolumn{3}{|c|}{$(\mathrm{Nam}+\mathrm{MNA}+2-\mathrm{Py}+4-\mathrm{Py})$ excretion } \\
\hline ( $\mu \mathrm{mol} /$ daily urine) & $3.94 \pm 0.45$ & $2.26 \pm 0.08$ \\
\hline Trp conversion factor & $43.5 \pm 5.1$ & $92.4 \pm 5.9$ \\
\hline$-=$ & 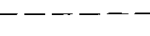 & -- \\
\hline \multicolumn{3}{|l|}{ Day 7} \\
\hline Body weight gain (g/day) & $1.5 \pm 0.2$ & $1.3 \pm 0.2$ \\
\hline Food intake (g/day) & $14.6 \pm 1.7$ & $15.3 \pm 1.6$ \\
\hline Trp intake $(\mu \mathrm{mol} / \mathrm{day})$ & $168 \pm 19$ & $176 \pm 18$ \\
\hline \multicolumn{3}{|c|}{$(\mathrm{Nam}+\mathrm{MNA}+2-\mathrm{Py}+4-\mathrm{Py})$ excretion } \\
\hline ( $\mu \mathrm{mol} /$ daily urine) & $3.89 \pm 0.55$ & $2.86 \pm 0.23$ \\
\hline Trp conversion factor & $44.5 \pm 4.5$ & $63.7 \pm 8.3$ \\
\hline
\end{tabular}

a Trp intake $(\mu \mathrm{mol} /$ day $)=[$ Food intake $(\mathrm{g} /$ day $) \times$ $0.903 \times 0.013 \times 0.2 \times 10^{6} \mathrm{~J} / 204.0 .903$, protein content in casein; 0.013 , Trp content in casein; 0.2 , casein content in the diet.

b Trp conversion factor $=[$ Trp intake $(\mu \mathrm{mol} / \mathrm{day})] /$ $[(\mathrm{Nam}+\mathrm{MNA}+2-\mathrm{Py}+4-\mathrm{Py})$ excretion $(\mu \mathrm{mol} / \mathrm{day})]$ Values are means \pm SEM for five rats.

related to these parameters. Figure 2 shows the effects of prednisolone on the urinary excretion of Nam, MNA, 2-Py and 4-Py. The rats were injected with prednisolone $(3 \mathrm{mg} / \mathrm{rat})$ or physiological saline three times at 09:00, 13:00 and 17:00 hr on day 0. Each excretion was higher in the prednisolone group than in the physiological saline group (control group) on the 1 st and 2 nd days after the injection. However, each excretion was lower in the prednisolone group than in the control group on the $3 \mathrm{rd}, 4$ th and 5 th days. On the 6th and 7 th days, each excretion tended to revert to the pre-injection values (day -1 ). Each urinary excretion in the control group was almost constant during the experiment.

Table III shows the effects of prednisolone on the body weight gain, food intake, Trp intake and Trp conversion factor. Body weight was decreased on the 1st and 2nd days after the injection, and increased again on the 3rd day and thereafter. Food intake in the prednisolone group was also decreased on the 1 st and 2 nd days as compared with the control group. The urinary excretion of the sum of Nam, MNA, 2-Py and 4-Py was higher in the prednisolone group than in the control group on the 1st and 2nd days; however, it was lower in the prednisolone group than in the control group on the $3 \mathrm{rd}, 4$ th and 5 th days. From the 6th day, it tended to revert to the pre-injection level (day -1). The Trp conversion factor under normal conditions is around 50. This conversion factor was lower in the prednisolone group than in the control group on the 2nd day after the injection; namely, the conversion of Nam from Trp was increased by the injection. The highest Trp conversion factor in the prednisolone group, namely the lowest niacin formation from Trp, was observed on the 4th and 5th days. On the 7th day, these values had almost recovered to the preinjection value.

\section{Discussion}

Prednisolone was injected into normal rats three times at 09:00, 13:00 and 17:00 hr on day 0 of the experiment. An injection of prednisolone caused an increase in niacin formation from Trp on the lst day after the injection. However, its formation decreased from the 3 rd to 6 th days after the injection. The effects of prednisolone had disappeared by around the 7 th day after the injection. Blake and $\mathrm{Kun}^{6)}$ have reported that after rats had been injected with hydrocortisone $\left(5.2 \times 10^{-2}\right.$ $\mathrm{nmol} / \mathrm{kg}$ of body weight) and then sacrificed $6 \mathrm{hr}$ subsequently, the liver Trp oxygenase activity increased about 9-fold. Sanada and Miyazaki ${ }^{4)}$ reported that after hypophysectomized rats had been injected with prednisolone $(2.5 \mathrm{mg} / \mathrm{rat})$ four times at 12 - $\mathrm{hr}$ intervals and 
sacrificed 12-hr after the last injection, the liver Trp oxygenase activity did not change as compared with the control up to $84 \mathrm{hr}$ after the last injection. Furthermore, Sanada and Miyazaki ${ }^{4)}$ reported that after hypophysectomized rats had been injected with both prednisolone $(2.5 \mathrm{mg} / \mathrm{rat}$ ) and somatotropin (a pituitary hormone, $1 \mathrm{mg} / \mathrm{rat}$ ) four times at 12 $\mathrm{hr}$ intervals and sacrificed 12-hr, 36-hr and 84hr after the last injection, the liver ACMSDase activity increased with time to a maximum value after $84 \mathrm{hr}$ (about 7 -fold higher than in the control). Hayakawa and Iwai ${ }^{10)}$ reported that after adrenalectomized rats had been injected with prednisolone $(3 \mathrm{mg} / \mathrm{rat})$ twice at 16:00 and 01:00 $\mathrm{hr}$ and sacrificed at 09:30 hr, the liver ACMSDase activity increased, although its increase was slight (about 2-fold) as compared with the control. These findings, ${ }^{4,6,10)}$ namely, a rapid elevation of Trp oxygenase level and slow elevation of ACMSDase level by adrenal cortical hormones, are consistent with the present results; rapid increases in the Nam, MNA, 2-Py and 4-Py excretion and subsequent decreases in each excretion thereafter were observed when prednisolone was injected into the rats. In other words, the initial increase and subsequent decrease in the urinary excretion of Nam and its metabolites is considered to be attributable to an elevation of Trp oxygenase level and an elevation of ACMSDase level, respectively. Accordingly, it was found that niacin formation from Trp increased initially, decreased subsequently, and reverted to its original level when prednisolone was injected into the rats.

The Trp conversion factor is considered to have affected the body weight change of the rats: when rats gain body weight, Trp and Nam are retained in the body; on the other hand, when rats lose body weight, Trp and Nam are released from the body. However, it is not clear how much Trp and Nam are retained in body when rats gain $1 \mathrm{~g}$ of body weight, and how much Trp and Nam are released from the body when rats lose $1 \mathrm{~g}$ of body weight. Therefore, this must be elucidated to calculate the real Trp conversion factor.

\section{References}

1) W. E. Knox, Brit. J. Exp. Pathol., 32, 462 (1951).

2) E. G. McDaniel, J. M. Hundley and W. H. Sebrell, $J$. Nutr., 59, 407 (1956).

3) A. H. Mehler, E. G. McDaniel and J. M. Hundley, J. Biol. Chem., 232, 331 (1958).

4) H. Sanada and M. Miyazaki, J. Nutr. Sci. Vitaminol, 26, $617(1980)$.

5) P. Greengard, G. P. Quinn and M. B. Reid, J. Biol. Chem., 240, 486 (1965).

6) L. Blake and E. Kun, in "Methods in Enzymology," Vol. XVIII, Part B, ed. by D. B. McCormick and L. D. Wright, Academic Press, New York, 1971, p. 113.

7) M. E. Pullman and S. P. Colowick, J. Biol. Chem., 206, 121 (1954).

8) K. Shibata, T. Kawada and K. Iwai, J. Chromatogr., 424, 23 (1988).

9) K. Shibata, Vitamins (Japan), 61, 599 (1987).

10) T. Hayakawa and K. Iwai, Agric. Biol. Chem., 49, 2431 (1985).

11) K. Shibata and H. Matsuo, J. Nutr., 119, 896 (1989). 